geological map at 1:5000 was made of a small area $10 \mathrm{~km}$ east of Fiskenæsset. In addition the best chromite horizons from an economic point of view were mapped at a scale of 1:1 000 and extensive sampling was continued throughout the region where chromite is known to occur.

The chromite occurs in the anorthosite in horizons 0.5-3 m wide which can be traced continuously for distances up to $4 \mathrm{~km}$. The chromite-bearing rock occurs as two types:

1) A layered type in which individual chromitite layers are generally 0.5 $2 \mathrm{~cm}$ wide, occasionally $7-10 \mathrm{~cm}$ and, in a few places, up to $1 \mathrm{~m}$.

2) An augen type characterized by plagioclase porphyroblasts in a matrix of chromitite.

The augen type is the more common in the region as a whole and in general forms horizons a little wider than the layered type. These augen-type horizons reach a maximum width of about $20 \mathrm{~m}$.

Chromitite layers $0.5-1 \mathrm{~cm}$ wide occur also in inclusions of ultrabasic rocks within the anorthosites.

The chromite is often associated with magnetite, and rarely with ilmenite and sulphide minerals.

There are chromite horizons in nearly all the anorthosite horizons. The chromite-bearing horizons can be followed for several tens of kilometres. They are not continuous as two periods of folding have boudinaged the original layers and have produced a complicated outcrop pattern.

FIELD WORK IN THE FREDERIKSHÅB AREA

Stig Bak Jensen

The systematic geological mapping of the area in West Greenland between $60^{\circ} 30$ and $62^{\circ} 00^{\prime} N$, i. e. between the fjord Sermiligârssuk and the town Frederikshåb, was begun by GGU in 1963. The aim is to publish two geological maps in a scale of 1:100 000. The area is the northern continuation of the Ivigtut area which was mapped by GGU in the years 1954-1960. Reron- 
naissance mapping up to 1960 mainly by $\mathrm{A}$. Berthelsen revealed many features of the geology, and was a help in the practical planning of the field work.

In 19634 geologists began mapping in the southern part of the area assisted by the GGU cutter "K. J.V.Steenstrup". In 1964 a new base camp "Mellembygden" was established $20 \mathrm{~km}$ north-east of Frederikshåb from which all assistance for the field teams was organised. In 1964 and subsequent years 2 Bell helicopters and the cutter "K. J. V. Steenstrup" provided the geologists with the necessary transport. The mapping was carried out by 12 geologists in 1964, 11 in 1965 and 12 in 1966. Only small parts of the Neria area remain to be mapped in 1967, and in the same year the mapping will be extended north of Frederikshåb as far as Frederikshåb Isblink $\left(62^{\circ} 30^{\prime} \mathrm{N}\right)$, also with "Mellembygden" as base. The mapping of this northern area should be completed in 1968 .

The field season lasts from early June to early September. The size of an individual geologist's area is between 150 and $250 \mathrm{~km}^{2}$, which is planned to be mapped in two field seasons. Some larger areas require three field seasons:

The western part of the area is covered by 1:20 000 topographical maps and the eastern part by 1:100 000 (the latter have been enlarged to 1:20 000 for field use). The area is covered by vertical aerial photographs, and there is a good cover of oblique photographs.

Geology of the Neria area

Field investigations have shown that dykes of Gardar age and supracrustals of Ketilidian age are present in the Neria area, and have also demonstrated the widespread occurrence of pre-Ketilidian gneisses.

The pre-Ketilidian gneisses are mainly biotite and hornblende-biotite varieties of granodioritic composition. The gneisses may be banded, veined or homogeneous. They have been strongly metamorphosed and intensely folded, and a succession of phases of folding can be demonstrated from many parts of the area.

The gneisses often contain amphibolite bands locally containing relic pillow structure, and in the eastern part of the area also occasional bands of brown garnet-mica schists. These serve as marker bands which are of particular value in the elucidation of the structural history. Anorthosite horizons encountered in the west of the area are of interest in that similar rocks have been reported in the gneisses of the Fiskenæsset-Godthåb (Windley, this report) and Ivigtut regions. 
In the south of the Neria area broad bands of greenschists and hornblende schists are found within the gneisses north and south of Sermiligârssuk. Within these bands some of the basic rocks still preserve pillow structures, and transformed psammites, pelites and carbonate-bearing rocks also occur. These supracrustals may be regarded as the remnants of a sedimentaryvolcanic sequence and have been collectively defined as the Tartoq Group.

The Tartoq Group supracrustals have migmatitic relationships with the bordering gneisses, and at least some of the gneisses are transformed Tartoq Group deposits. Other parts of the gneisses may represent extensions of the Tartoq Group stratigraphy or may comprise rocks of earlier periods. Gneisses and the Tartoq Group supracrustals on Midternæs are overlain unconformably by Ketilidian sediments.

Throughout the area several generations of metadolerite dykes transect the pre-Ketilidian gneisses. Some cut the Tartoq Group supracrustals but none are known to intersect Ketilidian rocks. The metadolerite generations have three main trends, N-S, NE and ESE in order of age, the oldest N-S dykes occurring mainly in the eastern part of the area. Locally several phases of NE trending dykes have been distinguished. The dykes are only weakly metamorphosed. In the south of the area the metadolerites are often sheared along their margins and a few examples are deformed by what appear to be Ketilidian structures. Further south in the Ivigtut area the same metadolerites are completely transformed and have been described as discordant amphibolites.

It can be concluded that the metadolerites are younger than the preKetilidian gneisses and supracrustals, probably older than the Ketilidian rocks, and definitely older than the Ketilidian deformations.

Ketilidian sediments and volcanics are found on Midternæs in the south-east part of the Neria area where they rest unconformably on preKetilidian rocks. The Ketilidian rocks of Midternæs can be correlated with the type Ketilidian succession in Grænseland, which lies just south of Midternæs, and can be referred to two groups: a lower, mainly sedimentary group (the Vallen Group) and an upper, mainly volcanic group (the Sortis Group). Higher levels of the Sortis Group not present in the type area are found on south-east Midternæs and a large neighbouring nunatak and consist mainly of pillow lavas.

Two main Ketilidian phases of folding deform the Ketilidian rocks of Midternæs, and also to a limited extent the adjacent pre-Ketilidian rocks; occasional folded metadolerites have been noted. Ketilidian metamorphism was weak. 
A narrow swarm of basic dykes trending $120^{\circ}$ crosses the Neria area and cuts the Midternæs Ketilidian rocks. These dykes, and a few scattered examples with trends of about $140^{\circ}$, predate the main Gardar dykes and may be of late Ketilidian age.

Several generations of Gardar dykes are found in the Neria area. The oldest are thin lamprophyres found mainly in the south of the area. They are succeeded by several generations of broad brown dolerites (B.D. s) with ESE to $\mathrm{NE}$ trends. Locally up to 7 successive phases of B.D. $\mathrm{s}$ have been established from intersections. A few narrow trachytes are also known.

There are many major tear faults in the area mainly with WNW, NE or E-W trends. Some of these faults can be shown to have been active at several different occasions between pre-Ketilidian and post-Gardar time.

The youngest dykes are coast-parallel dolerites (T.D.s) which postdate all other events (dykes and faults) apart from a few small carbonatite dykes, which have recently been found in the area around Frederikshåb. The carbonatite dykes are less than $1.5 \mathrm{~m}$ wide, are dark grey with a rusty weathering and contain porphyritic pyroxene and biotite. They have the same trend as the T.D.s which they cut and are probably of similar age.

\section{QUATERNARY DEPOSITS IN THE FREDERIKSHÅB DISTRICT, SOUTH-WEST GREENLAND}

\section{Kelly}

The Quaternary geology of an area of approximately $3000 \mathrm{~km}^{2}$ in the vicinity of Frederikshåb has been mapped during the summers 1964-1966. In this part of Greenland the unglaciated land between the outer coast and the margin of the Inland Ice is $40-70 \mathrm{~km}$ wide. The ice-free area is mostly a plateau at about $1000 \mathrm{~m}$ with isolated tops reaching $1600 \mathrm{~m}$, and is deeply dissected by fjords some of which reach the ice margin. Small cirque glaciers occur in the higher parts of the plateau.

Quaternary deposits cover extensive areas though they are generally 